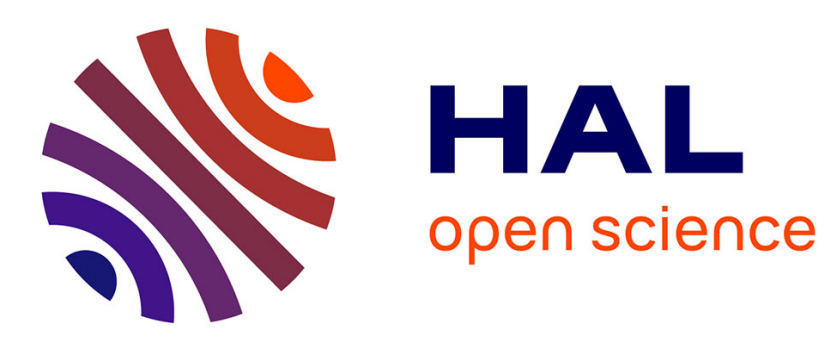

\title{
The origins of geoprospective
}

\author{
Christine Voiron-Canicio, Emmanuel Garbolino
}

\section{To cite this version:}

Christine Voiron-Canicio, Emmanuel Garbolino. The origins of geoprospective. Ecosystem and Territorial Resilience: A Geoprospective Approach, pp.1-23, 2020, 10.1016/B978-0-12-818215-4.00001-8 . hal-03318727

\section{HAL Id: hal-03318727 \\ https://hal.science/hal-03318727}

Submitted on 17 Sep 2021

HAL is a multi-disciplinary open access archive for the deposit and dissemination of scientific research documents, whether they are published or not. The documents may come from teaching and research institutions in France or abroad, or from public or private research centers.
L'archive ouverte pluridisciplinaire HAL, est destinée au dépôt et à la diffusion de documents scientifiques de niveau recherche, publiés ou non, émanant des établissements d'enseignement et de recherche français ou étrangers, des laboratoires publics ou privés. 


\title{
The origins of geoprospective
}

\author{
Christine Voiron-Canicio ${ }^{1}$ and Emmanuel Garbolino ${ }^{2}$ \\ ${ }^{1}$ Université Côte d'Azur, CNRS, Laboratory ESPACE, Nice, France, ${ }^{2}$ Climpact Data Science, \\ Nova Sophia-Regus Nova, Sophia Antipolis Cedex, France
}

\section{Chapter Outline}

1.1 In the beginnings, the prospective approach 1

1.1.1 Prospective and temporalities 3

1.1.2 Scenarios, collective thinking, and debating: the foundations of prospective 3

1.1.3 The fields of prospective: territorial prospective and environmental prospective 5

1.2 Stage 2 of prospective: taking into account geographic and sociospatial differentiations

1.2.1 Spatial differentiations and multilevel interactions 8

1.2.2 Challenging generic models 9

1.2.3 Combining generic and local prospective scenarios 10

1.2.4 From spatial change to spatial prospective 11

1.3 The emergence of geoprospective 13

1.3.1 The first mentions of geoprospective 13

1.3.2 New geographical studies claiming to belong to geoprospective or spatialized prospective 14

1.3.3 A construction at the interface of several fields of research 15

1.4 Conclusion 18

References 19

\subsection{In the beginnings, the prospective approach}

Geoprospective originated in the French geographers' community some 15 years ago. Research works in environmental and territorial dynamics presented at symposiums revealed a converging interest in the issue of the spatial change to come, and the models to use for anticipating it, not for predictive purposes but with a view to helping in reflecting on the future evolution of the spaces that were studied.

The purpose of this chapter is to go back over the steps which led to that convergence. The foundations of geoprospective have to be found within the discipline of geography, and more specifically in the field of spatial analysis. They also rest on the contributions of other disciplines and fields of research, the first of these being prospective. 
Prospective appears at the beginning of the 20th century, as a result of the Great Depression which shook the United States, when the forecasting methods used until then were put into question (Didier, 2009). After the end of the Second World War, it developed in two centers, the United States and France, that devised anticipation methods with specific orientations for each of them. On the American side, the Rand Corporation was created, as a laboratory of prospective methods-like the Delphi method, for example-focused on technological forecasting approaches mostly conducted in a military context. On the French side, the necessity to move from a still rural economy to an economy that would be at the same time industrial and more competitive coincides with the appearance of a prospective attitude which takes a fresh look at forecasting methods and at the end goal. So, in the mid1950s, the philosopher, Gaston Berger, initiated a new reflection on how to anticipate the future and on the methods used for making decisions and set up the Centre d'Etudes Prospectives. He contrasted a vision of the future freed from fatalism and the dependence on the past with the determinism stemmed from the positivist vision. "Tomorrow will not be like yesterday. It will be new and will depend on us" (Berger, 1957, 1958, 1967). The purpose of prospective is to prepare decisions and actions taking into account both changes in society and the potential impact of decisions on its development and, furthermore, in adopting a global approach to complex phenomena. Berger's pioneering work was continued on through the 1960s and 1970s by Bertrand de Jouvenel, the founder of the Futuribles Group (Association Internationale de Futuribles) which introduced the use of scenarios to construct positive images of the future or "scientific utopias" (De Jouvenel, 1967). Since the 1970s, the work of the French pioneers has been expanded on by Godet (1979).

The translation of the French word prospective is still a matter of debate, sometimes translated by Futures Studies, forecasting, foresight. More than a translation problem, this reveals the existence of different conceptions between the two sides of the Atlantic. As an example, Michel Godet explains in one of his books that the concept of prospective failed for a long time to find an appropriate translation. Forecasting is judged by Michel Godet as too influenced by economic modeling and technological forecasting (Godet, 2001). It was in 1996 that the relationship was established between prospective and foresight in an article about him: "The starting point of foresight, as with la prospective in France, is the belief that there are many possible futures" (Martin, 1996, 2010). However, the correspondence is not perfect, because Foresight expresses the image of a given future whereas prospective designates at the same time a process, the result of this process and the preparation of a plan of action for powering the change wished for. Because of this voluntarist and strategic dimension of prospective, which is one of the specificities of the French viewpoint as compared to the American approach, Michel Godet recommends the use of the expression strategic foresight or strategic scenario building (Godet, 2001). 


\subsubsection{Prospective and temporalities}

The specificity of the prospective approach stems from the way time-past, present, future-is taken into account in anticipating possible futures. Very often, the vision of the future is formatted by the past and kept in check by the tyranny of short-termism. Gaston Berger wrote in 1957: "Our civilization is breaking away from the fascination of the past with difficulty. Of the future, it only dreams and, when it works out projects that are no longer mere dreams, it draws them on a canvas on which it is still the past that is cast. It is stubbornly retrospective. It should become prospective" (Berger, 1957). Prospective seeks to inform society on the issues that both individuals and territories will have to confront in a distant future. This concern about long-term phenomena echoes the one which, at the beginning of the 1970s, underpinned the work of the Club of Rome and the publication of The Limits to Growth, first emblematic example of global and systemic prospectives conducted on a global scale (Meadows et al., 1972).

Prospective intends to distinguish itself from extrapolation by the ambition to explore the future without extending the present. Nevertheless, the representation of possible futures is dependent on the importance given to the facts of the present. Conceptually speaking, the dynamics of the future come from the forces of change and forces of inertia which put a brake on evolutions. Then, it is important to identify them and to spot, among present events, future-oriented facts, weak signals, and bifurcation points. To do so, there is no universal technique, the prospective interpretation of the lessons of the past and facts of the present remains an art.

\subsubsection{Scenarios, collective thinking, and debating: the foundations of prospective}

Prospective is a discipline made up of various branches-territorial prospective, strategic prospective, and environmental prospective-developed from a common conceptual base. These branches share the common aim to make stakeholders aware of the implicit hypotheses on which their action is based and rest on the principle of freedom of action which enables individuals to have a hold on their future. Whatever the field of study, prospective consists in seeing far and wide in order to assess the consequences of decisions, carrying out an in-depth analysis so as to go beyond analogy and extrapolation, and anticipating potential breaks. On the other hand, it broadens the representations of the future to qualitative approaches and data that are not solely quantified. For example, it gives a dominant place to the points of view of stakeholders in the future.

Scenarios, collective thinking, and debate are the mainstays of the prospective approach. Exploring the future consists in working out a range of future visions, which have to be sufficiently varied to apprehend the possible evolutions of the system being studied, sufficiently contrasted to be discussed, and also pertinent, and to help in decision-making. 
Such exploration is carried out by building scenarios, an essential step in the prospective approach. These were introduced in the United States in the 1960s by Herman Kahn when he was working with the RAND Corporation, then at the Hudson Institute. Kahn defines the scenario as "a hypothetical succession of evens built with a view to highlighting causal sequences and decision nodes" (Kahn and Wiener, 1967). At the same time, in France, an interdepartmental government organization known as DATAR (the Office for Regional Planning and Development) launched the first prospective exercise on the image of France in the year 2000 .

Nowadays, the term scenario encompasses different conceptions as well as a variety of methods and practices: the "experts" narrative of possible futures-probable, imaginable, plausible - , the systemic analysis, the quantitative or qualitative prospective model casting into the future a set of interrelated data and describing the future reality of the territory in an abstract manner. A scenario can be the reproduction of a scenario drawn up in a similar context and considered as being of interest for the situation in question. The aim of scenarios integrated into the prospective approach is to describe the future according to different options: a trend hypothesis_- business as usual—vs hypotheses intentionally contrasted, introducing from the onset, or along the way, one or several "breaks"; forecasting vs backcasting approaches; building a general model vs variations of the benchmark model. There are three main schools of scenario building (Houet, 2015; Amer et al., 2013; Bradfield et al., 2005):

- The "intuitive logics" consists in drawing up, in group, plausible narratives of causal chains without resorting to mathematical algorithms (Wack, 1985; Huss, 1988; Wright et al., 2013; Derbyshire and Wright, 2017).

- The "probabilistic modified trends" made up of two different methods. The first-the trends-impact analysis - forecasts future trends based on past trends and introduces unprecedented events likely to bring about deviations from the extrapolated trend. The second - the cross-impact analysis - adds a higher complexity level with the analysis of the interdependence of events taken by two, depending on whether they have already occurred or not, in order to correct initial probabilities given by experts (Bradfield et al., 2005; Bishop et al., 2007).

- The "prospective school" (Godet, 1986) differentiates itself from the two previous families by a more elaborate approach, mechanist, and less intuitive. The construction of scenarios relies heavily on computerized mathematical models. The number of steps in the methodological method varies depending on the authors (Durand, 1972; Godet, 1986; Schwartz, 1996; Schoemaeker, 1993; Mermet and Poux, 2002).

Whatever the method, the collective thinking process is always integrated into the prospective approach, but in variable forms, and is more or less present in the various stages of the approach. It is indispensable for identifying the key variables of the dynamic 
of the system being studied, for analyzing the stakeholders' strategies and, in synthesis, for bringing forward major issues for the future. It is as much useful in the subsequent stages, to move from problems to prospects, then from prospects to processes. True, the future will never match a given scenario exactly, but the latter provides a working basis, a contribution to the ongoing debate in a prospective forum (Mermet, 2005).

Since the 1990s, there have been an increasing number of studies and references on scenario methods in the scientific literature, as well as a proliferation of examples of scenarios in the public domain (Martelli, 2001). The scenario method is now widespread because it is seen as an effective dialogue tool between the various players involved in the implementation of a policy (Levêque and Urien, 2005).

\subsubsection{The fields of prospective: territorial prospective and environmental prospective}

\subsubsection{Territorial prospective}

The aim of territorial prospective is to work out visions, prospects, and orientations concerning the evolution of a territory and its inhabitants so as to provide information and help to take a stance and strategic options in the most complex cases (Loinger and Spohr, 2004). Planning should not be mistaken for the territorial prospective exercise. Guy Loinger points out that planning consists in putting into perspective a set of development projects, sectorial programs, policies, etc., based on predictive analyses. Whereas planning does not take into account the opinion of stakeholders and the social acceptability of the planned future, in the case of territorial prospective, "it is a question of collectively building a vision of the future with other working methods and starting from broader and more 'questioning' representations of the past and the present" (Loinger and Spohr, 2004). There are different movements of territorial prospective that are classified in three main families: "cognitive prospective," which questions the future based on assessments, situation evaluations, diagnoses, and surveys; "participative prospective" in which the future is worked out with the participation of stakeholders; "strategic prospective," which sets a set of goals to reach within a certain time limit, and a plan of action to succeed in reaching them.

In France, prospective is almost exclusively associated with public policy and planning. The "French-style" prospective conducted by DATAR from 1963 to 2014 goes together with the production of scenarios illustrating cartographically the voluntarist development promoted by the State (Delamarre, 2002). We will mention among these, the "scenario of the unacceptable" - an image of France in the years 2020 to be proscribed-, a contrario, the "network polycentrism"- -scenario desired for France in 2020_, and finally, all 28 scenarios on spatial systems in France, Europe, and the world, drawn up within the framework of “Territoires 2040," DATAR's latest prospective exercise (Cordobes, 2010). 
From now on, the territories of EU member countries, from city to region, handle prospective themselves, anticipate evolutions, and define their own strategy (Van Cutsem and Roëls, 2012). Indeed, an abundance of strategic prospective exercises has been observed, conducted at both the local and regional levels, and generally underpinned by scientific research work.

For example, since 2007, the ESPON program, financed by the EU Structural Funds, has been carrying out scientific studies on regional development which are intended for providing the knowledge needed for the first stage of any territorial prospective study. The European Environment Agency also carries out prospective studies. An illustration of this is the PRELUDE project, which explores plausible long-term evolutions for land use and their environmental impact (EEA, 2007). It is modeled using contrasting scenarios combining information relating to five areas of intervention and action which are determining in the trajectories of land use change: protection of the environment, solidarity and equity, governance and public intervention, optimization of agriculture, technology, and innovation. Modeling is carried out by applying a grid with cells of $18 \mathrm{~km}$ a side on the European area. The results of simulations are presented in cartographic form. This project illustrates the current will to combine environmental and anthropic data in a fine-scale territorial prospective.

\subsubsection{Environmental prospective}

In response to the consequences, most often harmful (pollution, destruction of environments and species, exploitation of nonrenewable resources, soil erosion, etc.) of anthropic action on natural environments, biodiversity, health, and the economy, the scientific community and territorial decision-makers have become involved in studying the future of the environment with the aim of slowing down, stopping the degradation of the ecosystems, or even improving the quality of the natural habitats and our environment. Some of the concrete actions that have been deployed internationally include UNESCO's Man And Biosphere (MAB) program, which was established by UNESCO (United Nations Educational, Scientific and Cultural Organization) in 1971 and aimed at the time to reconcile the human with its environment.

In parallel with the MAB program, Donella and Dennis Meadows, with Jorgen Randers and William W. Behrens III, published in 1972, on behalf of the Club of Rome, the book entitled "The Limits to Growth." Based on an approach based on the work of Jay W. Forrester in the early 1960s on systems dynamics, this global foresight work presented different scenarios of global evolution of natural resources and population. Although not based on a spatially explicit approach, the different results of simulations of evolution by 2100 were particularly worrying: they showed a significant decrease in natural resources and an equally significant increase in pollution and atmospheric $\mathrm{CO}_{2}$ concentration. The consequences of the world demography were to be a major reduction of the population toward the end of the 21 st century. This foresight work has had the merit of raising public 
awareness, politicians, and industry on the risks generated by economic development that does not take into account the limits of natural resources. Moreover, the comparison between the values simulated in 1972 and those currently observed are quite similar for variables such as the average atmospheric $\mathrm{CO}_{2}$ content, the birth rate, the world population, and the reduction of arable land, for example. The two updates of these models published in 1992 and 2004 clarified and confirmed the evolutionary trends initially presented. This work stimulated a group of researchers who, in the following years, began researching the evolution of ecosystems, ecosystem services, and society. The accumulation of work highlighting the risks for mankind of an economy based on ever more consumptionconsuming growth of exhaustible resources and increasingly polluting led the United Nations, in 1987, to define the concept of "Sustainable development" in the famous Brundtland report. The World Commission on Environment and Development was asked by the UN General Assembly to decide on the establishment of a timetable to promote a change based on sustainable development by the year 2000 and beyond. Indeed, this commission had pointed out that the ecological imbalances observed over the last decades had accentuated the disparities between human populations, accentuating poverty, health, and food problems. Because of the idea of sustainability, the concept of sustainable development then means looking ahead. But how?

In 1988 the United Nations Environment Programme of the UNO and the WMO (World Meteorological Organization) established the Intergovernmental Panel on Climate Change (IPCC). The main objectives of the IPCC are to study the evolution of climate and its impacts on ecosystems and society and to propose strategies in order to prevent risks due to global warming. The first assessment report was published in 1990 and the last and fifth in 2014. IPCC gathers more than 800 scientists that expertized more than 9000 publications about climate change evidences, its evolution, the current and potential consequences on ecosystems and society, and the options to mitigate the climate change and its expected consequences on the territories. Due to the very large literature review, very different approaches contribute to design the scenarios of climate evolution and its potential impacts on many aspects of our society. Some of these studies are spatially explicit but they do not always integrate the stakeholders demand or issues in the definition of the problematics and/or in the perspective of use of the results for the society. Most of the works analyzed by the IPCC concerning adaptation planning are based on expert opinions and some multicriteria optimization approaches that integrate climate change scenarios.

In 2001, the UNO launched an assessment of the impact of human activities on ecosystem services called "Millennium Ecosystem Assessment" (MA) that was published in 2005. The scope of this work was to establish an overview of the state of the environment, ecosystem services, and human wellbeing and to assess their evolution within 2050 by integrating scenarios of human activities development and climate change. The scenarios of the MA integrate feedbacks between social and ecological systems and they also take into 
account the linkages between global and local socioecological processes by using qualitative storyline and quantitative modeling mainly based on IMAGE and IMPACT models. IMAGE model (Integrated Model to Assess the Greenhouse Effect) estimates the consequences of climate changes interaction on Land Use and Land Cover and the population at the global scale. IMAGE also estimated the Greenhouse Gas (GHG) releases provoked by these changes and the consequences on biodiversity. The IMPACT Model (International Model for Policy Analysis of Agricultural Commodities and Trade) was developed to assess the consequences of global changes on food availability and poverty by integrating data about climate change, water demand and availability, crops production, economy and regulation of the agriculture market. The model simulates the operation of commodity markets and the behavior of economic stakeholders in order to estimate the supply and demand for food products. The use of these two models is applied at national and continental scales. Even if they integrated a spatial representation of the results, we cannot consider that they are spatially explicit.

Finally, the French consortium AllEnvi (Alliance nationale de recherche pour l'Environnement) that gathers 12 founders from the highest research institutions produced in decembre 2016 a report on the evaluation of 307 scenarios applied on environmental prospective (De Menthiere et al., 2016). The study shows that the scenarios can be organized into 11 huge families that indicate the different trends of social and environmental evolutions in different countries. These scenarios are applied at national, continental (Asia, Europe, Mediterranean basin, etc.), or global scales. Most of them are based on expert knowledge and are not spatially explicit.

We can conclude that, in environmental prospective, most of the researches are based on methodologies combining expert knowledge and modeling techniques of land use, integrating the evolution of climate change. Most of them are not spatially explicit and when they are, it is not clear if they take into account the issues raised by the stakeholders.

\subsection{Stage 2 of prospective: taking into account geographic and sociospatial differentiations}

In the last 20 years or so, scientific work carried out in environmental sciences and research work initiated on sustainable development in the field of social sciences-economy, geography, sociology, political science-led to delving into a number of subjects, including multilevel relationship, and existing differentiations across space. Such questioning had the effect of bringing changes to prospective approaches.

\subsubsection{Spatial differentiations and multilevel interactions}

Within the framework of studies carried out by the IPCC, the global atmospheric models used are applied on the lower levels using downscaling methods (IPCC, 2007). However, 
despite the steady improvement of the models used, climate information resulting from forecasts is still too approximate at the local level to meet the requirements of impact studies and adaptation measures. The climate's spatial variability has long been demonstrated by geographers (Yoshimo, 1975; Oke, 1987; Beltrando, 2010; Bonnardot et al., 2012; Quenol, 2013). Due to topography and land use, local temperature variations can be equal or higher than the temperature rises simulated by IPCC scenarios. Taking into account this multiscale spatial variability in scenarios, and broadly speaking, the functioning of local-scale geosystems has now become a challenge for the scientific community and is still to this day one of the stumbling blocks of prospective climate modeling.

Furthermore, giving further thought to sustainable development and to the necessary adaptation to global changes brings about the notion of systemic complexity of which the multilevel interactions are one of the dimensions (Allen and Starr, 1982; Wu, 1999). As stressed by the French biophysicist and philosopher Henri Atlan, such complexity lies in the fact that an observer lacks information to account for the global significance of local phenomena, taking into account the information that the observer can acquire on these two levels (Atlan, 1979). The economist, Olivier Godard, in an incisive article published in 1996 in the journal Futuribles, draws attention to the error consisting in believing that sustainable development implies adopting the same approach at the various territorial scales-global, continental, national, and local (Godard, 1996). He enjoins researchers and prospectivists "not to mechanically transfer reasonings from one scale to another," arguing that ecological constraint has an absolute meaning only at the global level; at all other levels, exchanges, substitutions, and imbalances can occur. Thus ecological constraints are relative; in that sense, sustainable development is not fractal. Likewise, he makes the case that sustainability is nonadditive. Depending on the territorial scales considered, recommendations and priorities will not be the same (Godard, 1984, 1996).

\subsubsection{Challenging generic models}

The challenging of "universal" models applicable to all scales, from global to local, appears in a number of studies, and more particularly as regards the environmental prospective rooted in simple causality and biophysical determinisms (Fernandez et al., 2011). Questions are raised on the normative content of the hypotheses used for defining cause-and-effect relationships, and on the physical limits of the system being studied. The critical analysis conducted on the DPSIR (Driving forces-Pressures-State-Impacts-Responses) model is a perfect example of the foregoing. This model belongs to the family of analysis tools aimed at producing useful information for decision-making, in the context of public policies. In this perspective, they are designed with a view to reducing complexity via a chain of causal links, in order to measure, with easily understandable indicators, the state of a phenomenon, 
and to identify and monitor the pressures affecting it. Using the DPSIR model is strongly encouraged by the European Environment Agency as well as by the Organization for Economic Cooperation and Development (OECD) and the FAO (United Nations Food and Agriculture Organization). Now, work carried out in social sciences and based on its use in water prospective in Europe gave rise to reservations on using it without prior consideration of the territory being studied. The criticisms stress that the Driving Forces are "anonymous" and "a-temporal" and that neither the stakeholders nor the trajectory of the territory on which the model is built is taken into account; the perimeter of the model is solely centered on physical or biophysical elements - for example, watershed-yet, sociosystems are part of particular geographies which transcend physical limits (Fernandez et al., 2011). Then, the authors advise to apply the DPSIR model from various angles: resources, policies, main players, with variable scales. The advantage of these variations is, on the one hand, to better grasp the complexity of spatialized problems, "what is seen as passive in a scenario can become the level of response in another"; on the other hand, to build more relevant contrasted prospective scenarios, by taking into account differentiated operating logics depending on the nature and extent of the territorial context: Europe, administrative region, portion of river basin, etc. (Fernandez et al., 2011).

These criticisms of the normative models with a universal scope echo the analysis carried out in parallel on their use in public policies, and more precisely on the EU water framework directive (Kallis and Nijkamp, 2000). Ward et al. (1997) examined critically the European Union's environmental policy. They stressed that the environmental regulation at the high European level often does not account adequately for the variety of problematic situations experienced in the Member States, for example, between urban northern areas and rural southern ones.

\subsubsection{Combining generic and local prospective scenarios}

It is, notably, to avoid this pitfall that new approaches of multiscale and participative prospective modeling have come up within the framework of European research programs. The PLUREL project will be taken as an example. The PLUREL project was designed between 2007 and 2010, in the context of the sixth framework program for research and technological development; its aim is to define the possible trajectories of European territorial units by 2025. Its originality lies in the combination of two interlocked series of multiscale modeling. The first consists of four contrasted scenarios, adapted from IPCC's baseline scenarios in 2000. The second applies these four scenarios at the level of the urban areas of six European metropoles varying in size, territorial organization, and spatial planning of urban development. In all six towns, people involved in local governance were requested to transcribe, in experts' words, the principles of the four prospective scenarios in the development dynamics of their respective territories, including local constraints and the 
urban planning legislations specific to each European state. Simulations are carried out on the Ispra Joint Research Center's Moland modeling and simulation platform. The results of the simulations reflect the combination of processes applied both at the European scale and that of the urban area being studied, and are mapped at that scale (Chery, 2010; Chery and Jarrige, 2012).

\subsubsection{From spatial change to spatial prospective}

Geographers went late into anticipating the future; they rather tended to direct their research toward the organization of space, observing spatial differentiations, assessing the lines of force of French space in the European context (Eckert, 1996; Brunet, 1990). In 1998 Denise Pumain even wondered whether geography would be able to invent the future (Pumain, 1998). Since then, the challenge was taken up by geographers, most of them belonging to the theoretical and quantitative geography movement. Their research work first led them to study processes generating spatial change, then to explore the issue of anticipating change. At the beginning of the year 2000, spatial change was addressed from a theoretical and conceptual point of view by the geographers of the EPEES (Espaces Post-Euclidiens et Evénements Spatiaux) group, who devised the concept of spatial event (EPEES, 2000). Their thoughts focused on the transformation process of spatial systems. The selforganization theories that formalize system dynamics from their components' multiple interactions provide a key to understanding the relationship observed between temporal rhythms and changes in space. As an example, the apparent opposition between fast and numerous spatial changes and the near-stationary organization of space becomes understandable in the light of self-organization mathematical models which describe how the dynamics of a system reconciles micro, fast, and seemingly random fluctuations, and a slow dynamics at the macro level. These researchers also looked into the context which makes that an event triggers a process which will produce a new spatial repartition with different consequences for the same event, depending on the place where it happens, and also into the "unexpected" effects occurring in some places.

Studies carried out on spatial change led geographers to take a critical look at prospective. They questioned the fact that spatial dynamics were ignored. How can people write scenarios of the future evolution of a space without knowing its spatiotemporal trajectory? (Lajoie, 2005). Prospective cannot ignore that environmental and anthropic phenomena to come will affect space in a differentiated manner. Moreover, they questioned the notions of stake and stake-laden space referred to in prospective diagnoses. Public policy apprehends the evolution of a place in terms of stakes generally linked to social or environmental risk as well as the expectations of both the society and the authorities. A stake-laden space is then seen as a lever for action. Now, stake-laden spaces are often declared such in terms of priorities rather than as a result of analyses truly devoted to detecting them. The stake-laden 
spaces identified by geographers can be completely different, even in contradiction with those chosen by public policies. For Voiron-Canicio (2013), a stake-laden space is defined by three precise situations: either a space-area or place-where tensions crystallize, whether they be latent or expressed by permanent or episodic conflicts; or a space with a vital interest due to some remarkable elements-populations or resources, such evaluation being assessed in terms of the prejudice that would be caused if they disappeared, and the benefit resulting from keeping them or reintroducing them; or else a space of strategic interest, not for a category of players in particular, but for the functioning of a territory or the sociosystem considered, because of the strong probability of its transformation impacting the rest of the system. The stake-laden space thus defined puts into question the notion of general interest as it is usually regarded by public policies, that is, assessed in respect of the estimated needs of individuals rather than those of the land, considering the place in a functional manner, on an area defined at an administrative level, focusing on the short term rather than on the long term (Voiron-Canicio and Olivier, 2005a,b; VoironCanicio and Dutozia, 2017; Voiron-Canicio, 2013; Dutozia, 2013; Liziard, 2013).

All these geographical studies are based on the same premise: space is considered as both organized and organizing. Spatial systems carry a spatial heritage which exerts constraints on projects, decisions, and a society's behavior, but which is also a potential that agents reexamine and reassess constantly, depending on their needs and aspirations, in regard to the dynamics and potentialities of other territories (Voiron-Canicio, 2006).

The spatial prospective devised by Cécile Helle and Laure Casanova falls within this framework. It extends these works while directing them toward the measurement of the sensitivity of spaces faced with change, in a perspective of aid to decision-making (Casanova, 2010; Casanova and Helle, 2012). Attention is drawn to the preparation of spatial changes and the possibility to intervene on the evolution trajectory of a space, depending on the leeway available. For these authors, the purpose of spatial prospective is to "envisage the ways in which space can change and the incidences of such change, to better prepare it and be prepared to it, which amounts to questioning the modalities of a space's future differentiation" (Casanova, 2010). The mechanisms and factors of evolution of territorial systems are revealed by a diagnosis combining the spatial, temporal, functional, and perceptive dimensions.

Spatial prospective consists in studying the possibilities for the transformation of spaces, starting from the premise that some logics of evolution are more favorable to change than others. The approach is carried out in two phases: identifying the stage of evolution of the territories and identifying the "possibles" of territorial action. The first phase studies the territory's potentiality in connection with its specific qualities, its resources-those exploited and those latent, in reserve. Qualifying this potentiality "should enable one to apprehend the capability of a territorial system to continue as it is or to become another 
system likely to meet the requirements of (present and future) societies" (Casanova, 2010). In the second phase, the "possibles" of territorial action ensue, on the one hand, from the territory's sensitivity to change, that is, from the differentiated behavior of spaces faced with the same event as a result both of their specific qualities and their stage of development; and on the other hand, from the territory's degree of freedom, that is, from the part of constraint linked to the existing spatial organization, which is likely to influence the territory's future evolution. It is necessary to evaluate the degree of freedom in order to assess the leeway as regards development. The operational aim of spatial prospective for future actions of development lies in detecting both the moments and environments most favorable for change (Casanova, 2010).

These considerations and research in spatial analysis have opened up a new field of exploration of the spatial future. They generated a prospective approach the specificity of which is based on the importance given to the spatial dimension, and to the attention paid to spatiotemporal factors in anticipating changes.

\subsection{The emergence of geoprospective}

In the mid-2000s, several research movements converged on the issue of anticipating the evolution of spatial systems, by using a number of common or similar principles, methods, and operating modes, without referring to the term geoprospective in all the cases. And when the term was used, the prefix geo covered different contents according to the areas of application.

\subsubsection{The first mentions of geoprospective}

As far as we know, the term "geoprospective" was first introduced by the Bureau of Geological and Mining Resources (BRGM) in France, at the beginning of the 1980s, without being defined with precision, within the scientific and technical frameworks of studying the evolution of the geophysical properties of radioactive waste storage sites in order to ensure their containment (Gadalia and Varet, 1982). The aspect linked to assessing risks, in particular those eventually leading to the loss of containment of the radioactive waste storage site's geological structure, was already there at the origin of geoprospective. It was only in the mid-1990s that the term was defined more precisely: "The geoprospective approach aims to work out plausible and coherent scenarios of this natural evolution and to assess its consequences in order to draw profitable lessons in terms of the capacity of a site to accommodate a project, and even of devising the project itself. It thus contributes to scientific objectives (demonstrating the project's feasibility), also technological and operational (project optimization) and to decision-making (selection of sites, project acceptability)" (Godefroy et al., 1994). The term was used with this meaning in the works of 
the BRGM throughout the years 1980 and 1990 (Courbouleix, 1983; Godefroy, 1983; Gros, 1983; Canceill et al., 1985; Afzali, 1989; Afzali et al., 1990; Garcin, 1993; Godefroy et al., 1994) and until the mid-2000s (Casanova et al., 2004), while resorting to modeling techniques and tools for simulating the physical evolution of storage sites. For this reason, at a symposium organized by the National Agency for the Management of Radioactive Waste (ANDRA), the BRGM and Paris Ecole des Mines (Godefroy et al. 1994) went back on the evolution of geoprospective methods with, notably, the move toward models integrating artificial intelligence techniques and expert advice for constructing realistic scenarios.

These studies thus laid the foundations for the research claiming to belong to geoprospective, that is, integrating "the spatial expression of phenomena the impact of which can be relativized in comparison with different project opinions..." (Godefroy et al., 1994). Taking the spatial dimension into account (in parallel with the temporal dimension) in geoprospective studies is therefore clearly assumed by the BRGM, while explaining the importance of the specific transposition of methods and tools to local circumstances. However, whereas research work concerning the storage of nuclear waste is still ongoing, the term seems to have fallen into disuse at the BRGM after 2004. In parallel, in 1998 JeanPaul Ferrier published "Le contrat géographique ou l'habitation durable des territoires" (the geographic contract or sustainable housing in territories) in which the author introduces the term "geoprospective" in a more geographical context linked to considerations on sustainable development, without defining it precisely.

\subsubsection{New geographical studies claiming to belong to geoprospective or spatialized prospective}

It was only in the mid-2000s that geoprospective sparked renewed interest. Geoprospective is tied up with spatial modeling. The 2004 situation report of the CNRS' section 39 "Spaces, Territories and Societies" clarifies the scientific issues: "Existing expectations in geoprospective direct research towards the notions of unpredictability and emergence which are the main difficulties in that field. One of the stances taken by researchers consists in considering that emergences are not totally unpredictable. Analyzing and modeling spatial interaction help to grasp the complexity of dynamics, to simulate the geosystems' possible futures and to produce spatialized decision-making tools" (CNRS, 2004). The ESPACE laboratory, a joint research unit of CNRS, was a trailblazer by including geoprospective in its 2004-07 scientific program. Indeed, a line of research is devoted to working out a new kind of territorial diagnosis, more powerful than the standard diagnosis, aimed at searching, in the present, harbingers of change and emergence that could weigh heavily in the future organization of territorial systems and help in territory geoprospective.

Christine Voiron-Canicio, in her research on urban paralysis risks in times of disaster published in 2005, uses the term "geoprospective" to describe the approach combining 
spatial analysis, GIS, and spatial simulations, designed for anticipating the consequences of a crisis situation and help the town of Nice to become better prepared (Voiron-Canicio and Olivier, 2005a,b). In 2006, she defined the scope of geoprospective more precisely: "Its purpose, as in the case of territorial prospective, is to get to know and foresee in order to organize and decide, but its specificity is to anticipate the evolution of a territory by understanding its spatial dynamics and to spatialize, on the medium and large scale, the evolution scenarios, development recommendations and their spatial impacts. Therefore geoprospective is inconceivable without spatial modeling" (Voiron-Canicio, 2006). In parallel, Thomas Houet, in the context of a research on environmental prospective, suggested a spatially explicit simulation method of prospective scenarios aimed at detecting the influence of measures for adapting to the reform of the European Union's Common Agricultural Policy (Houet, 2006). He described this approach as spatialized prospective.

In the years that followed, new research works claiming to be geoprospective or spatialized prospective were carried out. Moreover, a social demand appeared for the scientific community to work out, test, and validate methods enabling to spatially simulate phenomena, and to quantitatively evaluate the consequences of policy choices. In 2011, researchers from four CNRS laboratories-ESPACE, EVS, GEODE, and LETG-working in that field, together with the CNRS Méthodes et Applications pour la Géomatique et 1'Information Spatiale research group (GDR MAGIS), organized a seminar on the theme "Geoprospective: contribution of the spatial dimension to prospective research." That seminar brought together some 50 participants and provided the first opportunity for exchanging views and debating on the various conceptions of this new research field as well as on achievements based on the use of the spatial element in territorial and environmental prospective. As a follow-up of the seminar, a "geoprospective" group was created within the GDR MAGIS, and two surveys were devoted to geoprospective, one in an issue of the review, L'Espace géographique (EG 2012-2), and the other in the online review Cybergéo.

\subsubsection{A construction at the interface of several fields of research}

Geoprospective is mainly driven and disseminated within the scientific community by geographers belonging to the movement of "theoretical and quantitative geography" and spatial analysis. Spatialized modeling and simulation, which are their common denominator, take various forms and are most of the time hybridized with methods stemmed from other lines of research, such as Land Change, Land System, Companion Modeling, and, of course, the prospective research stream.

\subsubsection{1 "Theoretical and quantitative geography" and spatial analysis}

In the past, a number of French geographers have taken a critical look at prospective:

"a highbrow and ambitious word supposed to give quality to guesswork about the future" 
(Brunet et al., 1992), while stressing the necessity to scrutinize, within spatial systems, the retroactions and risks of breakage or bifurcation. These issues and, more broadly, the prospective questioning, concern theoretical and quantitative geography as well as spatial analysis. By confronting structures and dynamics, forms, and flows, and by exploring the processes of spatial change, the latter is eminently spatiotemporal. De facto, spatial dynamics are carriers of geoprospective; "Geoprospective seen as an attempt to integrate spatial differentiation into the prospective approach is an obvious field of application of spatial analysis" (Charre, 2003).

Since the last four decades, the theoretical and quantitative geography movement endeavors to define the processes that generate spatial dynamics. To do so, it relies on various theories-more particularly on self-organization theories-and also on modeling and simulation. Two kinds of tools are used, on the one hand, macrodynamic models based on nonlinear differential equations, and on the other hand, tools that consider space as a collection of particles — cellular automata, multiagent system-which they use for trying to formalize the change of scale. Nowadays, this field of research faces a dual challenge. On the one hand, a shift of perspective with regard to change, with the aim to explain it ex ante and no longer a posteriori only. "By allowing to achieve, not an accurate prediction, but the exploration of a diversity of possible futures, will these models help to study the change in geographical structures in a nomothetic way?" (Pumain, 1998). Furthermore, will they help in the prospective formulation, and even in decision-making. Indeed, there is a great demand for geoprospective-oriented spatial models that would be within the reach of the highest possible number of executives so as to help them simulate the spatial impacts of an envisaged measure and evaluate how development policies can reinforce or constrain territorial dynamics. The specificity of the contribution of spatial analysis to prospective lies both in these spatiotemporal questionings and in the methodological, theoretical, and applied corpus designed for attempting to find answers (Voiron-Canicio, 2006).

\subsubsection{Land change science}

In the mid-1980s, two important programs concerning the transformations of ecosystems and land systems were launched: the Land Use and Land Cover Change Project (LUCC) in 1994 and its successor the Global Land Project in 2005. Both were interdisciplinary projects within the International Geosphere-Biosphere Program (IGBP) (Lambin et al., 1999) bringing together researchers in landscape ecology, biogeography, political ecology, resource economics geographical information and remote sensing, etc., aiming to understand the land use/cover change dynamics and their relationship with global environmental change. A new line of research referred to as land change or land system science emerged from these works; its aim was to try to understand the land use/cover change dynamics by interlinking social systems and ecosystems (Verburg et al., 2015). Research was carried out in four directions: observation and monitoring of land changes, understanding of these changes as a coupled 
human-environment system, spatially explicit modeling of land change, and assessments of system outcomes (Gutman et al., 2004; Turner et al., 2007). The favored methodology is that of "Integrated Assessment of the land system" (Kok et al., 2004). The main theme in the LUCC community is the modeling of land use dynamics and its social and environmental impacts. Scenarios is a second recurrent theme. Both models and scenarios can be developed by using participatory approaches (Kok et al., 2004). Research work carried out in that context strongly contributed to the development of prospective modeling and spatial simulation on land cover/use changes on various scales (GLP, 2005).

\subsubsection{Spatialized participatory approaches}

These approaches are characterized by the involvement of the stakeholders at every stage of the prospective process. The Companion Modeling approach is one of the best-known methods, and also the nearest to geoprospective. This approach appeared in 1996, then was developed and formalized by a community of researchers, the ComMod Network; it uses agent-based, GIS and role-playing game models as tools to help solve complex environmental issues involving several stakeholders. It consists in producing models shared by all to represent the functioning of the system being studied, helping in dialogue, and in fine, reach a solution accepted by all stakeholders (Bousquet and Le Page, 2004).

The participatory territorial prospective works lie at the crossroads of participatory approaches and territorial prospective (Piveteau, 1995; Lardon, 2013; Lardon an Roche, 2008; Lardon et al., 2016). They use spatial representation on various media-maps, landscape block diagrams, graphic models - as a mediation tool to foster the participation of stakeholders and their involvement in the collective action. "Prospective-action" makes use of the knowledge of researchers and stakeholders, mediatized via a participatory device based on spatial representations (Lardon and Roche, 2008) to produce both scientific knowledge and knowledge for action (Lardon et al., 2016).

Nowadays, these lines of research hybridize geoprospective much more than prospective does, although the approach originated from the latter (Fig. 1.1).

There is an imbalance between assessment prospective as a decision support, which is well represented on various scales, and academic prospective, both environmental and territorial, driven by a restricted circle of scientists. The reasons are various. The prevailing scientific posture is more focused on the analysis of past dynamics than on those of the future, which are more uncertain and controversial. Such uncertainty results in divergent analyses and difficulty validating affirmations concerning the conditions of the future. Eleonora Barbieri Masini et al. (1993) wrote on that subject: "the scientific nature of prospective is its most controversial characteristic, and in fact, for numerous researchers, it is not included in the qualities of prospective." Moreover, Laurent Mermet and Xavier Poux (2002) consider that the great majority of researchers involved in research work on the environment is in near 


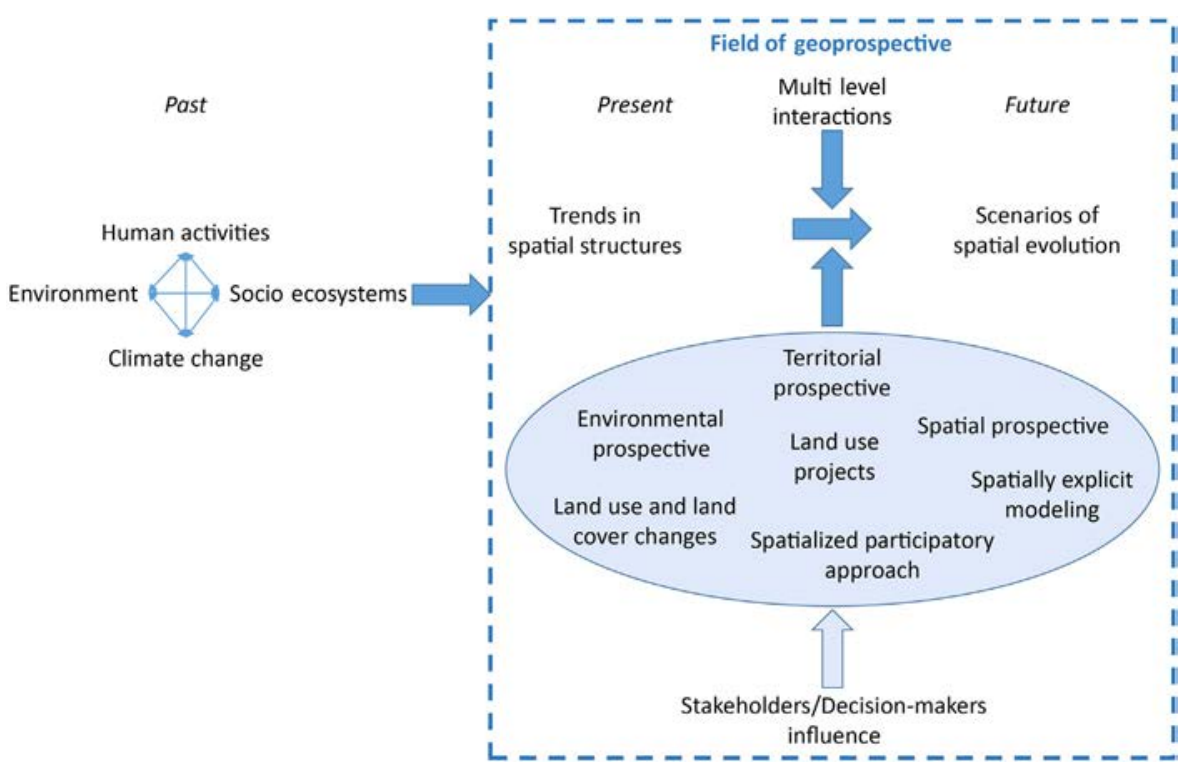

Figure 1.1

Geoprospective, at the interface of several fields of research.

total ignorance of theoretical questionings and methodological resources in works specialized in prospective.

\subsection{Conclusion}

Geoprospective is an emerging field of research driven by a reduced number of researchers, mostly French. Its singularity is due at the same time to its concept, its projects, and its practices. The concept is based on the central and essential place allocated to the spatial dimension in the medium-term and long-term anticipation processes of the evolution of the system being studied: ecosystem and territory.

As is the case with prospective, the target is to provide aid for action in public policy, planning, or management. However, the primary objective is of a scientific nature. The project of geoprospective is to consider, through research, the space being studied in its complexity, by trying to identify its structures and dynamics, and to understand the anthropic and environmental dynamics as well as their spatial interactions on different scales, and their impacts on the system being studied in the context of uncertainty about the future. This is a key issue, which falls within both fundamental and applied research. By associating theory and practice, the geoprospective posture tends to reduce the fundamental research/applied research dichotomy, which has become artificial in many respects in geography, but is still rooted in minds (Charre, 2003). 
Geoprospective is not a school, it is a posture open to different lines of research, which encompasses various methods and practices that take part in its construction, none of them being exclusive. The formalization of the approach is built on a small number of principles and basic rules which were consensual in the founding works and were adopted de facto (Voiron-Canicio and Olivier, 2005a,b; Voiron-Canicio, 2006; Houet, 2006; Gourmelon et al., 2012; Houet and Gourmelon, 2014):

- Taking into account the spatial dimension of the problem is the vital lead of the approach. The spatial reasoning underpins the various stages of the process of anticipating the future.

- The prospective is carried out using spatialized representations of possible futures. The scenarios and models, whether quantitative or qualitative, aim to detect the spatial impacts of changes to come.

- The end application of the knowledge resulting from the geoprospective approach is aid to action.

- Geoprospective is a scientific approach. Spatial representations and models of the future cannot be validated by conventional methods, but nevertheless must meet the criteria of likelihood, pertinence, coherence, and usefulness.

Those researchers who choose to link their works to the field of geoprospective implicitly adhere to these rules, by inscribing their research in the wake of the founding works which they reference. Nevertheless, divergences exist over two points, the kind of modeling approach used and the inclusion of stakeholders in the course of the geoprospective approach. The choice of spatial modeling of the future varies according to the theme, the usual practices of the disciplines, and depending on the researcher's methodological background: quantitative model vs qualitative model, spatialized scenarios vs spatially explicit scenarios. The strongest discrepancies concern the place allocated to stakeholders in the development of the approach. The stakeholders' implication is strong in geoprospective approaches regarding territorial prospective, the integrated management of a resource or an area-littoral, mountain,.--, risk adaptation; it is more limited and still rather rare in the case of climate, hydrology, or biodiversity issues.

This unstabilized formalization can be disconcerting and is being debated. Should the approach be made more normative, and a School of geoprospective be created? Or should the freedom of practices be retained and the experimentation of methods combining diverse contributions be encouraged?

\section{References}

Afzali, H., 1989. Géoprospective: développement de la modélisation. Evaluation des vitesses d'altération et d'érosion dans divers contextes. BRGM, Département Stockage, 27p. (in French). 
Afzali, H., Fourniguet, J., Peaudecerf, P., 1990. Géoprospective: développement de la modélisation. Évaluation des vitesses d'altération et d'érosion dans divers contextes. Direction générale. Science, recherche et développement, 37p. (in French).

Allen, T.F.H., Starr, T.B., 1982. Hierarchy: Perspectives for Ecological Complexity. University of Chicago Press, Chicago, IL.

Amer, M., Daim, T.U., Jetter, A., 2013. A review of scenario planning. Futures 46, 23-40.

Atlan, H., 1979. Entre le cristal et la fumée. Essai sur l'organisation du vivant. Seuil, Paris (in French).

Barbieri Masini, E., Bell, W., Boulding, E., 1993. La prospective et les tendances à l'unité et à l'adversité. Revue Internationale des Sciences Sociales 137, 387-461 (in French).

Beltrando, G., 2010. Les géographes-climatologues français et le changement climatique aux échelles régionales. EchoGéo 2010, 14 (in French). <http://echogeo.revues.org/11816> (accessed 17.05.19.).

Berger, G., 1957. Sciences humaines et prévision. Revue des Deux Mondes, n 3 : 417-426, Etapes de la prospectives, sous la direction de Jean Darcet, 1967. Presses Universitaires de France, 337p. (in French).

Berger, G. (Ed.), 1967. Etapes de la prospective. PUF, Paris.

Bishop, P., Hines, A., Collins, T., 2007. The current state of scenario development: an overview of techniques. Foresight 9, 5-25.

Bonnardot, V., Carey, V., Madelin, M., Cautenet, S., Quénol, H., 2012. Using atmospheric and statistical models to understand local climate and assess spatial temperature variability at fine scale over the Stellenbosch wine district, South Africa. Int. J. Vine Wine Sci. 46 (1), 1-13.

Bousquet, F., Le Page, C., 2004. Multi-agent simulations and ecosystem management: a review. Ecol. Model. 176, 313-332.

Bradfield, R., Wright, G., Burt, G., Cairns, G., Van Der Heijden, K., 2005. The origins and evolution of scenario techniques in long range business planning. Futures 37, 795-812.

Brunet, R., 1990. Evaluation et prospective des territoires. In: Conférences sur la géographie. Ministère de la recherche et de la technologie, Paris, pp. 25-44 (in French).

Brunet, R., Ferras, R., Thery, H., 1992. Les mots de la géographie, dictionnaire critique. Reclus Montpellier. La Documentation Française, Paris (in French).

Canceill, M., Courbouleix, S., Fourniguet, J., Godefroy, P., Gros, Y., Manigault, B., Peaudecerf, P., 1985. Etude geoprospective d'un site de stockage: Simulation de l'evolution d'un site a l'aide du programme "Castor". Sciences et techniques nucléaires, Bureau de Recherches Géologiques et Minières, vol. 9, 69p. (in French).

Casanova, L., 2010. Les dynamiques du foncier à bâtir comme marqueurs du devenir des territoires de Provence intérieure, littorale et préalpine: éléments de prospective spatiale pour l'action territoriale, thèse, Avignon (in French).

Casanova, L., Helle C., 2012. Ce que les dynamiques foncières révèlent du devenir des territoires: éléments de prospective du sud-est français, L'Espace géographique 2012/2, Tome 41 (in French).

Casanova, J., Brach, M., Millot, R., Négrel, Ph., Petelet-Giraud, E., 2004. Projet PALEOHYD II. Paléohydrologie et géoprospective: modèles conceptuels et processus d'acquisition de la chimie des eaux dans les massifs granitiques. Rapport d'avancement. Rapport BRGM/RP-52880-FR, 66p. (in French).

Charre, J., 2003. Programme scientifique 2004-2007 de l'UMR ESPACE. Université d'Avignon et des Pays de Vaucluse, Avignon (in French).

Chery, J.-P., 2010. Les espaces périurbains en Europe: un grand écart entre description et prospective. In: Prospective périurbaine et autres fabriques de territoires. Datar. Territoires 2040, pp. 61-76 (in French).

Chery, J.-P., Jarrige, F., 2012. Scénarios prospectifs et modélisation des changements d'utilisation des sols: les dynamiques de périurbanisation dans la région de Montpellier à l'horizon 2025. 48ème colloque de l'Association de Science Régionale de Langue Française (ASRDLF), 2011, Schoelcher. Available from: $<$ hal-00655815 $>$ (in French).

CNRS, 2004. Rapport de conjoncture, section 39 du Comité national. CNRS, Paris < http://www.cnrs.fr/ comitenational/doc/conjoncture.htm\#2004> (accessed 17.05.19.) (in French).

Cordobes, S., 2010. Les plis de territoire 2040. In: Délégation à l'Aménagement du Territoire et à l'Action Régionale, Territoires 2040. La Documentation Française, Paris (in French). 
Courbouleix, S., 1983. Etude géoprospective d'un site de stockage. Climatologie: évolution du climat et glaciations. Rapport B.R.G.M., no 83 SGN 143 GEO, Orléans, France, 136p.

De Jouvenel, B., 1967. The Art of Conjecture. Basic Books, New York, NY.

De Menthiere, N., Lacroix, D., Schmitt, B., Bethinger, A., David, B., Didier, C., et al. (Eds.), 2016. Visions du futur et environnement: Les grandes familles de scénarios issues d'une analyse de prospectives internationales relatives à l'environnement. Rapport du GT Pros-pective au Conseil d'AllEnvi, vol. 1: rapport final de l'étude ScénEnvi, vol. 2: recueil des fiches prospectives (in French).

Delamarre, A., 2002. La prospective territoriale. La Documentation Française, Collection Territoire en Mouvement, Paris (in French).

Derbyshire, J., Wright, G., 2017. Augmenting the intuitive logics scenario planning method for a more comprehensive analysis of causation. Int. J. Forecast. 33, 254-266.

Didier, E., 2009. En quoi consiste l'Amérique? Les statistiques, le New Deal et la Démocratie. La Découverte, Paris (in French).

Durand, J., 1972. A new method for constructing scenarios. Futures 4, 325-330.

Dutozia, J., 2013. Espaces à enjeux et effets de réseaux dans les systèmes de risques, Thèse de doctorat de Géographie, Université Nice Sophia Antipolis, Nice (in French).

Eckert, D., 1996. Evaluation et prospective des territoires. Reclus Montpellier. La Documentation française, Collection Dynamiques du territoire, Paris (in French).

EPEES, 2000. Evénement spatial. L’Espace Géographique 29-3, $193-199$ (in French).

European Environment Agency, 2007. Land-use scenarios for Europe: quantitative and quantitative analysis of a European scale. Copenhague, EEA Technical Report No. 9.

Fernandez, S., Bouleau, G., Treyer, S., 2011. Reconsidérer la prospective de l'eau en Europe dans ses dimensions politiques. Développement Durable et Territoires 2 (3), (in French).

Gadalia, A., Varet, J., 1982. Etude géoprospective d'un site de stockage. L'activité volcanique. Rapport BRGM 83 SGN 010 STO, 20p. (in French).

Garcin, M., 1993. GEOPROSPECT TD (Time Dependant): Démonstrateur d'atelier de géoprospective. BRGM, Département Géologie, 30p. (in French).

Garcin, M., Godefroy, P., Djerroud, A., Rousset, M.C., 1994. Application des techniques de l'intelligence artificielle à la géoprospective: le projet Expect. Colloque Géoprospective—, 1994. UNESCO, Paris, France, 6p. (in French).

GLP, 2005. Global Land Project. Science plan and implementation strategy. IGBP Report No. 53/IHDP Report No. 19. IGBP Secretariat, Stockholm.

Godard, O., 1984. Autonomie socio-économique et externalisation de l'environnement: la théorie néo-classique mise en perspective. Economie Appliquée XXXVII (2), 315-345 (in French).

Godard, O., 1996. Le développement durable et le devenir des villes: bonnes intentions et fausses bonnes idées. Futuribles 1996, 29-35. Available from: < hal-00624329> (in French).

Godefroy, P., 1983. Etude géoprospective d'un site de stockage. La prise en compte de l'activité sismique. Rapport BRGM 83 SGN 301 GEG, 144p. (in French).

Godefroy, P., Courbouleix, S., Fourniguet, J., Garcin, M., Gros, Y., Peaudecerf, P., 1994. Evolution des concepts, méthodes et outils de la géoprospective. Colloque Géoprospective, 18-19 avril 1994. UNESCO, Paris, pp. 89-91 (in French).

Godet, M., 1979. The Crisis in Forecasting and the Emergence of the Prospective Approach: With Case Studies in Energy and Air Transport. Pergamon Press, Oxford.

Godet, M., 1986. Introduction to la prospective: seven keys ideas and one scenario method. Futures 18, 134-157.

Godet, M., 2001. Creating Futures: Scenario Planning as a Strategic Management Tool. Economica, London.

Gourmelon F., Houet T., Voiron-Canicio C., Joliveau T., 2012. La géoprospective, apport des approches spatiales à la prospective. l'Espace géographique 2, 97-98 (in French).

Gros, Y., 1983. Etude géoprospective d'un site de stockage. Tectonique prospective: durée des phases compressives et distensives récentes, évolution du champ de contraintes dans les 100000 ans à venir. Rapport BRGM 83 SGN 210 GEO, 67p. 
Gutman, G., Janetos, A., Justice, C., Moran, E., Mustard, J., Rindfuss, R., et al., (Eds.), 2004. Land Change Science: Observing, Monitoring, and Understanding Trajectories of Change on the Earth's Surface. Kluwer Academic, New York, NY.

Houet, T., 2006. Modélisation prospective de l'occupation du sol en zone agricole intensive: evaluation par simulations dynamiques de l'impact de l'évolution des exploitations agricoles dans la France de l'Ouest. Norois 198 (1), 35-47 (in French).

Houet, T., 2015. Usages des modèles spatiaux pour la prospective. Revue Internationale de Géomatique 25 (1), $123-143$ (in French).

Houet, T., Gourmelon, F., 2014. La géoprospective-Apport de la dimension spatiale aux démarches prospectives. Cybergeo: Eur. J. Geogr. (in French). <http://journals.openedition.org/cybergeo/26194> (accessed 17.05.19.).

Huss, W.R., 1988. A move toward scenario analysis. Int. J. Forecast 4, 377-388.

IPCC, 2007. IPCC. Climate Change: The Physical Science Basis. Summary for Policymakers. Contribution of the Working Group I to the Fourth Assessment of the Intergovernmental Panel on Climate Change. $<$ https://www.ipcc.ch/report/ar4/wg1/> (accessed 17.05.19.).

Kahn, H., Wiener, A.J., 1967. The Year 2000. A Framework for Speculation on the Next Thirty-Three Years. Macmillan, New York.

Kallis, G., Nijkamp, P., 2000. Evolution of EU water policy: a critical assessment and a hopeful perspective. J. Environ. Law Policy 3, 301-335.

Kok, K., Verburg, P., Veldkamp, T., 2004. Integrated assessment of the land system: the future of land use. Land Use Policy 24, 517-520.

Lajoie, G., 2005. Modélisation et prospective territoriale. In: Guermond, Y. (Ed.), Modélisation en Géographie: Déterminismes et Complexité. Hermès, Paris, pp. 107-143. (in French).

Lambin, E.F., Baulies, X., Bockstael, N., Fischer, G., Krug, T., Leemans, R., Moran, E.F., Rindfuss, R.R., Sato, Y., Skole, D., Turner, B.L., Vogel, C., 1999. Land-use and land-cover change (LUCC): implementation strategy. In: A Core Project of the International Geosphere-Biosphere Programme and the International Human Dimensions Programme on Global Environmental Change. IGBP Report 48. IHDP Report 10. IGBP, Stockholm.

Lardon, S., 2013. Developing a territorial project. The territory game, a coordination tool for local stakeholders. FaçSADe 38, 1-4.

Lardon, S., Roche, S., 2008. Représentations spatiales dans les démarches participatives: production et usages. Revue Internationale de Géomatique 18 (4), 423-428 (in French).

Lardon, S., Marraccini, E., Filippini, R., Gennai-Schott, S., Johany, F., Rizzo, D., 2016. Prospective participative pour la zone urbaine de Pise (Italie): l'eau et l'alimentation comme enjeux de développement territorial. Cahiers de géographie du Québec 60 (170), 265-286 (in French).

Levêque, C., Urien, R., 2005. Préface. In: Mermet, L. (Ed.), Étudier des écologies futures: un chantier ouvert pour les recherches prospectives environnementales. Ecopolis 5, 13-17 (in French).

Liziard, S., 2013. Littoralisation de la façade nord-méditerranéenne: Analyse spatiale et prospective dans le contexte du changement climatique, Thèse de géographie, Université Nice Sophia Antipolis (in French).

Loinger, G., Spohr, C., 2004. Prospective et planification territoriales: Etat des lieux et propositions, Note du Centre de Prospective et de Veille Scientifique No. 19 (in French).

Martelli, A., 2001. Scenario building and scenario planning: state of the art and prospects of evolution. Futures Res. Q. Summer 17 (2).

Martin, B.R., 1996. Technology Foresight: capturing the benefits from science-related technologies. Res. Evaluation 6 (2), 158-168.

Martin, B.R., 2010. The origins of the concept of foresight in science and technology: an insider's perspective. Technol. Forecast. Soc. Change 77, 1438-1447.

Meadows, D., Meadows, D., Randers, J., Behrens, W., 1972. The Limits to Growth. Universe Books, New York, NY. 
Mermet, L. (Ed.), 2005. Étudier des écologies futures: un chantier ouvert pour les recherches prospectives environnementales. Ecopolis 5 (in French).

Mermet, L., Poux, X., 2002. Pour une recherche prospective en environnement-repères théoriques et méthodologiques. Natures, Sciences, Sociétés 10 (3), 7-15 (in French).

Oke, T., 1987. Boundary Layer Climates, second ed. Routledge, London.

Piveteau, V., 1995. Prospective et territoire: apport d'une réflexion sur le jeu. Etudes Gestion des territoires, 15, Cemagref Editions (in French).

Pumain, D., 1998. La géographie saurait-elle inventer le futur. Revue Européenne des Sciences Sociales, Tome XXXVI 110, 36-69 (in French).

Quenol, H., 2013. Climate analysis at local scale in the context of climate change. Pollution atmosphérique, mai 2013.

Schoemaeker, P.J.H., 1993. Multiple Scenario development: its conceptual and behavioral foundation. Strategic Manag. J. 14, 193-213.

Schwartz, P., 1996. The Art of the Long View: Planning for the Future in an Uncertain World. Currency Doubleday, New York, NY.

Turner, B., Lambin, E., Reenberg, A., 2007. The emergence of land change science for global environmental change and sustainability. Proc. Natl Acad. Sci. U.S.A. 104 (52), 20666-20671.

Van Cutsem, M., Roëls, A., 2012, Cosmopolis, No. 3-4.

Verburg, P., Crossman, N., Ellis, E.C., Neihimann, A., Hostert, P., Mertz, O., et al., 2015. Land system science and sustainable development of the earth system: a global land project perspective. Anthropocene 12, 29-41.

Voiron-Canicio, C., 2006. L'espace dans la modélisation des interactions nature-société. Actes du Colloque International Interactions nature-société, analyses et modèles, La Baule, mai 2006. Available from $<$ halshs-02133213> (in French).

Voiron-Canicio, C., 2013. Déceler les espaces à enjeux pour l'aménagement. In: Masson-Vincent, M., Dubus, N. (Eds.), Géogouvernance, utilité sociale de l'analyse spatiale. Collection Update, Editions Quae, Versailles, pp. 171-182 (in French).

Voiron-Canicio, C., Dutozia, J., 2017. Anticiper et simuler les dynamiques de changement pour diagnostiquer et améliorer la résilience d'un système territorial urbain. Risques urbains. $<$ https://www.openscience.fr/ Anticiper-et-simuler-les-dynamiques-de-changement-pour-diagnostiquer-et $>$ (accessed 17.05.19.) (in French).

Voiron-Canicio, C., Olivier, F., 2005a. Using a GIS to anticipate the consequences of urban paralysis when a disaster strikes: application to the city of Nice (France). In: Systèmes d'information géographique et gestion des risques, ISTED, Paris-La Défense. Available from: < halshs-02098378> (in French).

Voiron-Canicio, C., Olivier, F., 2005b. Simulations et détection des espaces à enjeux dans un système urbain, en situation d'inondation. Actes du Colloque International SAGEO 2005, Avignon. Available from $<$ halshs02133218> (in French).

Wack, P., 1985. Scenarios: uncharted waters ahead. Harv. Bus. Rev. 63, 139-150.

Ward, N., Lowe, P., Buller, H., 1997. Implementing European water quality directives: lessons for sustainable development. In: Baker, S., Kousis, M., Richardson, D., Young, S. (Eds.), The Politics of Sustainable Development. Global Environmental Change Series. Routledge, London.

Wright, G., Bradfield, R., Cairns, G., 2013. Does the intuitive logics method-and its recent enhancementsproduce effective scenarios? Technol. Forecast. Soc. Change 80, 631-642.

Wu, J., 1999. Hierarchy and scaling: extrapolating information along a scaling ladder. Can. J. Remote. Sens. 25 (4), 367-380.

Yoshimo, M., 1975. Climate in a Small Area: An Introduction to Local Meteorology. University of Tokyo Press, Tokyo. 